7. Maystrovsky, M. T. (1997). Museum exposition (theory and practice, art of exposition) / M. T. Maystrovsky M. : AST: Astrel [in Russian]. Ukrainian].

8. Olenina, O. Yu. (2010). Transformation of art in the communicative culture of society. Kharkiv : KhDAK [in

9. Svirko, V. O. \& Boychuk, A. V. \& Goloborodko, V. M. \& Rubtsov, A. L. (2014). Designing activity: the state and prospects. Informational and methodical publication K. : UkrNDI DE [in Ukrainian].

10. Polisevich, R. The Ukrainian stand on Dutch Design Week http://royaldesign.ua/ru/ukranskiy-stend-nadutch-design-week.bXvGD/ [in Ukrainian].

Стаття надійшла до редакції 09.12.2019 р. Прийнято до публікації 24.12.2019 p.

UDC 78.078

Tatarnikova Anzhelika

Candidate of Pedagogical Sciences, doctoral candidate, lecturer at the Department of Theoretical and applied Cultural studies of the Odessa National Musical Academy named after A.V. Nezhdanova. ORCID 0000-0002-6310-8276 angelikatatarnikova75@gmail.com

\title{
"LIBUSE" by B. SMETANA IN TERMS of CULTURE THE NATIONAL GLORIFICATION
}

The purpose of the article is to highlight the positions of the current side of the Opera concept of "Libushe". It is relevant for the modern creative life of Smetana, where the signs of national glorification are concentrated, indicative, as a principle of expression, for the postmodern and post-postmodern cultural space. The methodology of the research is based on art criticism focusing on the culture of glorification. It comes from the cult instructions in the concept of $P$. Florensky, developments in the culture of dithyramb in O. Losev, ideas about the religious and cult principles of positive ritual in E. Durkheim. Art criticism in the development of cult installations of B. Asafiev's research considers the principles of consideration of the composition "Libushe" by B. Smetana and defines analytical, historical-descriptive, comparativestylistic, interdisciplinary-comparative methods. The scientific novelty of the work is as follows: for the first time in the domestic cultural studies and artistic developments focused attention on the cultural phenomenon of worship as part of the expression of the national idea of the composition of the musical-a stage performance called Opera. Conclusions. Generalization of the spiritual-semantic and dramaturgical specifics of "Libushe" Would. B. Smetana allows us to put forward the concept of quasi-liturgical content of the named work. This poetics reveals creative and ideological parallels to the stage performance of "Ruslan and Lyudmila" by M. Glinka as the "Slavic Liturgy". According to B. Asaf'ev, both before Wagner's musical and theatrical heritage and its mythopoetic attitudes and before the Pasion of J. S. Bach-piest, he realized that Lutheranism was in contact with the Byzantine liturgical practice.

Key words: "Libushe" by B. Smetana, cult, culture, national glorification, liturgical foundations of the composition structure, pietism by Y.S. Bach.

Татарнікова Анжеліка Анатоліївна, кандидат педагогічних наук, докторант, викладач кафредри теоретичної та прикладної культурології Одеської національної музичної академії ім. А. В. Нежданової

«Лібуше» Б. Сметани у вираженні культури національного славлення

Метою даної роботи є висвітлення позицій актуальної для сучасного творчого буття сторони оперної концепції «Лібуше» Б. Сметани, в якій зосереджені ознаки національного славлення, показові, як принцип вираження, для постмодернового і пост-постмодернового культурного простору. Методологічною основою дослідження покладено мистецтвознавчі зосередження на культурі уславлення, що походять з культових настанов в концепції П. Флоренського, розробок з культури дифірамбу у О. Лосєва, уявлень про релігійно-культові засади позитивного ритуалу у Е. Дюркгейма, а також мистецтвознавче спрямування у розробках культових установлень в дослідженнях Б. Асаф'єва. Відповідно, аналітичний, історико-описовий, компаративно-стильовий, міждисциплінарно-порівняльний методи визначають принципи розгляду композиції «Лібуше» Б. Сметани. Наукова новизна роботи полягає у наступному: вперше у вітчизняному культурознавстві і мистецтвознавчих розробках зосереджена увага на культурному феномені славлення як складової вираження національної ідеї у композиційному рішенні музично-сценічної дії названої опери. Висновки. Узагальнення духовно-смислової та драматургічної специфіки «Лібуше» Б. Сметани дозволяє висунути концепцію quasi-літургійного наповнення названого твору, поетика якого виявляє творчо-ідеологічні паралелі і до сценічного дійства «Руслана і Людмили» М. Глинки як «слов'янської літургії» за Б. Асаф'євим, і до вагнерівського музично-театрального спадку та його міфопоетичних настанов, і до пасіону Й. С. Баха-пієтиста, що усвідомлював контактність лютеранства з візантійською літургійною практикою.

Ключові слова: «Лібуше» Б. Сметани, культ, культура, національне славлення, літургійні засади будови композиції, пієтизм Й. С. Баха.

(c) Tatarnikova A., 2020 
Татарникова Анжелика Анатольевна, кандидат педагогических наук, докторант, преподаватель кафедры теоретической и прикладной культурологии Одесской национальной музыкальной академии им. A. B. Неждановой

\section{«Либуше» Б. Сметаны в выражении культуры национального славления}

Целью данной работы является освещение позиций актуальной для современного творческого бытия стороны оперной концепции «Либуше» Б. Сметаны, в которой сосредоточены показатели национального прославления, показательные как принцип выражения для постмодернового и пост-постмодернового культурного бытия. Методологической основой исследования выступают искусствоведческие сосредоточения на культуре прославления, исходящие из культовых установок концепции П. Флоренского, разработок по культуре дифирамба А. Лосева, представлений о религиозно-культовых основах позитивного ритуала у Э. Дюркгейма, а также искусствоведческое направление в разработках культовых установлений у Б. Асафьева. Соответственно, аналитический, историко-описательный, компаративно-стилевой, междисциплинарно-сравнительный методы определяют принципы рассмотрения композиции «Либуше» Б. Сметаны. Научная новизна работы заключается в следующем: впервые в отечественном культуроведении и искусствоведческих разработках сосредоточено внимание на культурном феномене прославления как составляющей выражения национальной идеи в композиционном решении музыкально-сценического действия названной оперы. Выводы. Обобщение духовносмысловой и драматургической специфики «Либуше» Б. Сметаны позволяет выдвинуть концепцию quаsiлитургического наполнения названного произведения, поэтика которого выявляет творческо-идеологические параллели и со сценическим действом «Руслана и Людмилы» М. Глинки как «славянской литургии» по Б. Асафьеву, и с вагнеровским музыкально-театральным наследием и его мифопоэтическими установками, и с пассионом И. С. Баха-пиетиста, осознававшего контактность лютеранства с византийской литургийной практикой.

Ключевые слова: «Либуше» Б. Сметаны, культ, культура, национальное прославление, литургийные основы строения композиции, пиетизм И. С. Баха.

The relevance of the stated topic is determined by the all-Slavic significance of B. Smetana's legacy. The musical development of the national principle of the composer's creativity has a deep meaning in the creative, practical and theoretical use of the present, when the processes of global globalization and integration are combined with the trends of local and regional distributions in the world and internal national life. The "Libouche" opera is a definite exception in the dramatic search of the nineteenth century, since the explicit epic-lyrical composition of its music is not compatible with the positions of musical drama, indicative of romanticism, thus preceding the non-dramatic concepts of Opera and stage cantata-oratorio of the twentieth century.

The opera, according to the plan of B. Smetana himself, embodies female heroism, which had certain parallels to the image of Wagner's brunhilde, but bypassing the tragic and dramatic tension of the image of the German Valkyrie. The composer himself saw a parallel of his work to Wagner's "Meistersingers", but the feminized essence of the heroic idea is quite sharply opposed to the masculine representation of the concept of national reconciliation in this work of the German composer. In addition, with all the features of the epic drama in the named work of G. Wagner also shows signs of a musical drama of the type of German romantic Opera indicative of this author with a pronounced conflict, which is represented by the confrontation of individual (Walter) and individual (Sachs) beginnings, fans of the national Association (the Opera was created on the eve of the national unification of Germany) and those who ideologically-creatively (Beckmesser) and spontaneously-inertially (the inhabitants of Nuremberg) oppose this.

B. Smetana's Opera has certain parallels to M. Glinka's "Ruslan", the essence of which was noted by B. Asafiev as "the Slavic Liturgy of Eros" [1], as well as to the search for a stage cantata-oratorio of the XIXXX centuries, the principles of which were established in the musical and stage sphere of the last century.

The analysis of research and publications devoted to the work of B. Smetana, in particular, the Opera "Libushe", is presented by the monograph of I. Martynov, the works of I. Belzi, as well as historical essays of M. Druskin [4]. However, most of them were published in the middle of the last century, representing the creativity of B. Smetana under a certain ideological "angle". However, the actualized experience of modernity-twentieth century avant-garde and post-modernism of the last decades of spiritual and symbolic component and clavelina Opera classics poetics of Czech music (including in "Libuse") until visual in domestic musicography literature, although it is this legacy Would B. Smetana can be very useful when presenting the modern theory of musical and stage drama and practical embodiments in the productions of the corresponding performances.

The purpose of this work is to highlight the positions of the current side of the Opera concept of "Libushe" that is relevant for modern creative life B. Smetana, where the signs of national glorification are concentrated, indicative, as a principle of expression, for postmodern and post-postmodern cultural life.

Methodological work of the study put art focus on the culture of glorification, based on the cult installations in the concept of P. Florensky, developments in culture, sing the praises of O. Loseva [6], ideas about the religious principles of positive ritual from Durkheim as well as art direction in the development of the iconic plants of B. Asafiev [1], in the works of O. Muravskii [8]. Accordingly, analytical, historical-descriptive, comparative-stylistic, interdisciplinary-comparative methods determine the principles of considering the composition of B. Smetana "Libushe". 
Presentation of the main material. The Opera "Libushe" by B. Smetana was written by the composer as a "Czech holiday Opera" [10, p. 658], dedicated to the celebration of the foundations of the Czech state (1872). The author has been waiting for its production for almost 10 years. The premiere took place in 1881, although even then the sick composer, according to him, could not cover the entire scope of such an event. The text was written in German by I. Wenzig and was subsequently translated into Czech by E. Spindler. At the center of the Opera action are the life steps of the legendary Princess libusche, the founder of Prague, who managed to achieve national harmony and thus lay the high ideals of the unity of the nation, who survived the hardest historical trials and had the opportunity to assert herself in the nearest historical perspectives.

The evaluation of this Opera is ambiguous. In M. Druskin's book of essay " The Opera" legacy of B. Smetana is stated that " the Main types of Smetana operas are heroic and comic. Their most striking examples: "Dalibor", "Sold bride"...". And at the same time, in the further presentation, the author quotes the words of the composer's self-assessment: "This is my best work in the field of high drama" [4, p. 474]. On the pages devoted to the review of B. Smetan's Opera works as a whole. Regarding libouche, M. Druskin writes: " a special place in Smetana's work is occupied by the Opera "Libushe" (1871-1872). The composer called it a "solemn" picture " and insisted that it should not be used in everyday situations, but only in exceptional cases - on days of national holidays. This is how it is done in Czechoslovakia to this day" [4, 472-473]. And then there is the explanation: "Libushe is an epic and majestic work that glorifies (italics A. T.) the Motherland and the people."..> The tone of the narration is strict and solemn, the recitation is sublime, and the powerful choral frescoes give the Opera the image of a monumental oratorio ... " [4, 473].

The Opera named by B. Smetana stands out from what was written by his predecessors and contemporaries for its Frank glory, bypassing theatrical drama as such. The composition was composed in the significant year 1872, when he finished his "Heroic Symphony" and began writing "Prince Igor" by V. Borodin; when, a year earlier, the essentially heroic Opera "Siegfried" By G. Wagner was completed, as it is content-structurally central in the tetralogy "Ring of the Nibelung". From what has been said, it follows that B. Smetana clearly responded to the "call of time" (see about the" spirit of the era " in g. Hegel [2]), creating something majestic and heroic, in the glorification of the national heritage of the State, why the historical example was the events of 1871: the formation of a United Germany-Prussia and United Italy.

B. Smetana was clearly inspired by the political tendency of the state to reinforce the self-importance of the nation - this was the creation of "national Opera of the popular holiday type" [10, 658]. The work was planned as Coronation Opera for Kaiser Franz Josef I, who was to become king of Bohemia in Prague. But the situation changed somewhat, and the premiere of the Opera, which was to take place on November 12 , 1872, was postponed to June 11, 1881. Smetana was not included in the category of "popular" works, since it was obviously "heavy" in its depth and internal tension, rather it correlated with the operatic epic achievements of R. Wagner and representatives of the "Mighty bunch". Relations with the latter did not develop, but the support of F. List from R. Wagner's entourage was unquestionable.

According the compositions of A. Borodin and G. Wagner, with which the composition of B. Smetana has certain analogies, The latter stands out, as indicated earlier, for its self-sufficient female satire, as well as the unique character of conflict-free drama, which has no direct analogues among contemporaries. The entire Opera, as a whole, is resolved in the key of C-dur, recalling with its one-tone vibudovanistyu some operas-poems by G. Wagner ("the flying Dutchman" in d-moll, "Tristan and Isolde" in a-moll, "Nuremberg meistersingers" in C-dur). However, two of the named "one-tone" compositions have a state-of-the-art principle of presenting the drama, pronounced features of "demonism" in the thinking and actions of the characters, which ultimately leads to a tragic denouement. The only real analogue in this regard is the "Meistersingers", as the composer himself stated.

There is another sample of the Opera, which is correlative with the "Libushe" B. Smetana: "Ruslan and Lyudmila" by M. Glinka, whose huge composition is held around the key of D-dur, and in which conflict situations are pushed aside by pictorial comparisons of numbers-portraits of characters, individual or collective teams in choirs. The glorious principle of "Ruslana" is self-evident, as indicated by B. Asafiev, defining this work as "the Slavic Liturgy of Eros" [1, 15-34]. And the Frank conviviality and predominance of major keys of the work of M. Glinka and B. Smetana cream is really internally similar.

The differences are also obvious: M. Glinka has developed choral and ballet scenes, the characters are quite numerous, and the "liturgical" nature of the Opera is supported by a significant role in the action of large-scale choral scenes. "Libouche" is closer to R. Wagner's operas in its "loud-speaking chamber": the stage action is closer to the monopera, since the libouche part covers all the main points of the performance. There are seven characters in the Opera, and the monumental and powerful choruses have rather plot-stage episodic characteristics. Nevertheless, the liturgical character of the work's structural characteristics is manifested in the form of an unequal two-phase adjustment of the type and analogy suggested by B. Asafiev for the Orthodox Liturgy in relation to "Ruslan and Lyudmila": "the Liturgy of the catechumens" - "the Liturgy of the faithful".

In the case of "Ruslan", the parallel to the "Liturgy of the catechumens" is 4 acts from 5 acts, and in the final 5 acts, the art critic finds an analogy to the Liturgy of the faithful [1, p. 15-21], since the I-IV actions demonstrate the steps of testing for the heroes, while the $\mathrm{V}$ act shows their spiritual purification. This uneven 
distribution of semantic material in the composition does indeed have an analogy to the Orthodox service, since the part of the "Creed" that corresponds to the "I believe" is placed in the middle of the liturgical and ritual "space" for Catholics.

In this regard, the composition of B. Smetana in this Opera is clearly close to the Orthodox or oldChristian service, since two of the 3 acts almost completely cover information about the trials, and only in the final scene of act II there is a turn to spiritual Purification: Libushe refuses his crowned virginity, choosing the "noble of the peasants" as his wife, which cuts off attempts by Hrudosh and Styaglav through their princely inheritance to get the hand of the Princess. Libushe's decision is interpreted unambiguously in line with the heroine's" democratic " intentions, although ancient evidence of the farming of kings (Homer's Odyssey) attests to the unity of the peasant and chivalric cause. So Libushe, whether introducing a new motive for uniting various social strata, or restoring the forgotten archaic correlation of ploughmen and warring Nations, declares his meekness, giving the primacy of government in men's hands.

Act III, which presents libusche's last prophecy of the future glory of Bohemia, clearly embraces a meaning comparable to the Liturgy of the faithful. But, as in M. Glinka, the liturgical dynamics in the arrangement of the Opera composition is corrected with a solemn beginning - an Overture that provides for the thematic content of the final act, demonstrating the "picturesqueness" that I would mention. Sour cream, talking about your Opera.

Generalizing the intonation-dramaturgical specifics of "Libushe", we note that this Opera is not only monotonous, it is also monotematic: the initial theme, which represents the glory of Libushe, is built in the symbolism of Light and good power (from Pythagoras, a-b-c embody celestial entities, of which the tonality of $C$ indicates Strength [3, 239]). This same tonality is still a unity in the dramaturgy of G. Wagner's "Nuremberg meistersingers", the same tonality caused the delight of the "kuchkists" in the finale of the Second Symphony of P. Tchaikovsky with variations on the Ukrainian comic song "Zhuravel", which is powerful in its laughable expression.

Plot-stage conflict in the analyzed Opera of B. Smetana is planned for action, but at the end of the same act-is removed by the decision of Libushe is to cede power for the sake of the prosperity of the nation. Do not forget that blood-indicators of ethnic Slavs, the Czechs, due to the Celtic grounds (hence taken in the German world, the name of the Czech Republic-Bohemia, "land battles", i.e. the Celts) where tangible tradition of female activity in public life, and military exits. The libusche figure is a reminder of the Czech archaic connection with Celtic cultural foundations, the masculinization of which appeared in the Slavic entry into the Celtic area.

In the subject Libuse-the ruler that appears at the beginning of the Overture as the leading thematic material, having no opposition, but only additions (the second theme of tenderness Libuse, vol. 26) and comparison (subject Premysl, vol. 75, heroic Es-dur - tone is associated with the image of Charles IV In the prophecy of Libuse in the III action). This brings the structure of the Overture closer to the two-part reprise form (Reprise - vol. 114, Tempo I), in which the features of either the strophic structure or the old-time Sonata are recognizable. The latter are brought together in those Sonata "hints "of the construction of the songhymn construction" Zap-chorus", from which the foundations of the Sonata form have historically risen. The course of the major triad tones of the first theme of Libushe-Ruler is the basis of all other melodic-chord formations and, above all, this is demonstrated by the theme of Przemysl - Libushe's chosen one. And the rhythmic type of movement of the Hoda organically merges with this kind of rhythm in the quote of the Hussite hymn in the Opera's finale. In this last demonstration is obvious for vintage gymnotiform shift I, VI and VII natural melodic steps down from $\mathrm{d}$, which gives connectivity with the expressive power of natural in Libuse themes in which variability I and II degrees (that is, the variability principles $c$ and d) are similar virgulinoconnotation.

In General, the construction of the Opera to a certain extent unfolds the Reprise of the two-part nature that is claimed by the Overture, imitating the kind of variation of the "Intro-composition" in General that we find in R. Wagner, first of all, in his "Meistersingers". But the General idea of imitation - "Overture (Intro)" - "whole composition" - Would be solved. Sour cream in a fundamentally different dramatic way: In In the framework of the comic, though "weighted" with instructiveness, we have a dramatic conflict, which ends with the harmony of the conjugation of opposites, with the corresponding function of exposure-conflict in action I, developing-harmonizing opposites in action II, and "dynamic" - updated Reprise in action III, which together removes the grounds for conflict.

"Libuse" B. Smetana demonstrates the rudiments of drama in action I. Accordingly, themes, Libuse and the inherent colouring-dur rampant in the 1 st and 3rd scenes, and action (3rd - short form, only the second "theme soft" character), while in the 2nd stage have a blast claims Stagevu and Rugosa, their rivalry (from the main key), which removes the 3rd stage, abbreviated to feeding material scene №1. So in the construction of act 1 , we feel the connection with the structure of the Overture-introduction. And this same architectonic principle is seen in the design of the composite whole. These same structurally significant regularities, i.e. repetition-variation, not development, cover the entire Opera: the action develops the main image, and then the main dramatic node of the plot is discharged - a decision is made on the state-strengthening marriage of Libushe with her chosen one, that is, podiyovi moments are completed here. Act II is a portrait - 
indirect and direct-characterization of Przemysl, the chosen one of Libushe, act III, in the form of the last prophecy of the wise virgin Libushe glorifies what was done in the previous acts.

And the action has a dominant position in the sphere of C-dur in act II ( 5 scenes) we have a onetone ratio of c-moll - C-dur (1, 3-5 scenes), including this theme of Przemysl in C-dur (!), which sounded at the beginning of the second part of the Overture, forming a variative-rozryadzhuyuchu construction regarding events and images And the act. Act III demonstrates the exit from C-dur through the mediation of the "heavenly" (see above) color of a-dur into the glorious tonality of D-dur - because of the above-described emblematics of the C-d shift in the symbolically sounding Hussite hymn, correlating with the heroine's prophecy.

Note the fact that the traditional juxtaposition of male and female scenes in this Opera is "reversed": first there are female scenes, in which the heroic libouche complex reigns, followed by the male cast. And if the masculine principle prevails in both actions, in the presence of a female presence in romantic Opera, then, accordingly, the second action brings to the fore the feminine series (see" Free shooter "by K. Weber," Wilhelm tell " by J. R. Weber). Rossini, "The Huguenot" John. Meyerbeer et al.). According B. Smetana again, the opposite is true: the second action of "Libushe" is focused on showing Lyutobor and Przemysl, highlighted by Radovan. The appearance of Krasava with Rudozem a few "breaks" monolithic male structure of the scenes, but still, this last prevails.

Indicative is the fact that the main male lead - bass (Přemysl and Radovan baritones, and Khrudosh Lutobor bass as such). That is, the effect invented by M. Glinka-the ratio of bass (baritone) and soprano in the representation of a pair of prisoners (for example, Ruslan-Lyudmila in "Ruslan", and this Opera B. Smetana knew it well from its production in Prague in the 1860s, although personal relations with N. Balakirev and the "kupkists" of the composer did not develop), - the Czech master giperbolizuvav. After the specified timbre and the ratio indicative for a couple Libuse - Premysl, and Krasava of Rugosa. And this is a very significant parallel to the Slavic Orthodox Opera thinking:"...In the classic Russian Opera, couples in love <... they are often represented by a harmony of voices that is markedly different from the timbral harmonies of Western European Opera. In this last from the XIX century. the standard is: soprano-tenor, whereas in Russian Opera it is often bass (baritone) and soprano: Ruslan-Lyudmila in Glinka, Demon-Tamara in Rubinstein, Igor-Yaroslavna in Borodin <...> the "consistent antinomics" of voices is outlined, in the spirit of old Christian Church "antinomies", symbolizing the mental readiness to identify different things. $<\ldots>$ There is a certain timbral continuum, symbolizing the rationalistic clarity of distinguishing different things in the similar with the principle of "overcoming the semantics of matter" into a substrate of a single quality" [5, 80-81].

This is how the Orthodox sense of the Czech state glory is manifested on a conscious level - the Hussites, the soldiers for the Byzantine basis of Worship, who, in their spiritual and organizational order of battle, relied on the experience of the Zaporozhian Sich and formed an emblematic position for the Czech nation and state in it. Dramatic collisions are outlined and removed in the first act. Acts II and III make up gigantic stanzas-hymns in praise of what is stated at the end And the action. Accordingly-architecturally-we have a two-phase construction in the Opera composed of three acts, and, in the semantic interpretation of the preparation (and action) and the Completion (II-III actions), following the first Christian Orthodox Liturgy, in which the structural position is the ratio of the Liturgy of the Catechumens - the Liturgy of the Faithful.

Such a plan be the action of the Opera Asaf'ev saw in" Ruslan " M. Glinka, and, in indicative for Orthodoxy, the disproportion of the duration of the first prepotent phase and the rapidity-glory of the second glorifying one. $\mathrm{H}$. Markova sees this same liturgical two-phase nature in the schedule of the Bach Pasion [7, 128-132], which corresponds to the piety-Pro-Orthodox orientation of the Lutheranism of J. S. Bach [see: 9, 140-143], but with a reduction of the first phase of the liturgical action indicative of the Western Christian idea. A similar plan for the embodiment of liturgicality is found in the two-part spiritual oratorios in F. Mendelssohn's "Paul" and "Elijah", which clearly reinterpreted Bach's legacy. We have the same type of thinking, with conscious Parallels to Orthodox liturgics and spirals to bacchianism, in the plan of B. Smetana's Libushe, where the dramatic moments of preparation in the first act of the Opera are switched to the glorification of the chosen ones in the second and third acts.

The liturgical framework of the Opera "Libouche" was provided by the composer, who was eager to perform it on the Holidays of national unity. The author's pan-slavistic tilt of thinking and real contact with the liturgically constructed Opera "Ruslan and Lyudmila" by M. Glinka determined the" starting point " of the author's architectonic thinking, while the proximity to $G$. Wagner and Bohan's Pro-turgian motivation of thinking determined the original fusion of the compositional indicators of the whole as a semantic two-phase prepared - Fulfillment in the three-act composition "Libushe" by B. Smetana.

Conclusions. Generalization of the spiritual-semantic and dramatic specifics of B. Smetana's "Libushe" allows us to put forward the concept of quasi-liturgical content of the named work, the poetics of which reveals creative and ideological Parallels to the stage performance of M. Glinka's "Ruslan and Lyudmila" as a "Slavic Liturgy" by B. Asafiev and to Wagner's musical-theatrical heritage and its mythopoetic settings, and to the Pasion Of Lutheranism with Byzantine liturgical practice.

\section{תimepamypa}

1. Асафьев Б. Симфонические этюды. Л.: Музыка, 1971. 264 с. 
2. Гегель Г. Лекции по истории фрилософии. URL: https://mybook.ru/author/fridrih-gegel/lekcii-po-istoriifilosofii-2/read/ (дата звернення: 05.09. 2019 р.).

3. Гудман Ф. Магические символы. М.: Золотой век, 1995. 289 с.

4. Друскин М. История зарубежной музыки. Вторая половина XIX века. М.: Музыка, 1980. Вып. 4. 528 с.

5. Каминская-Маркова Е. Н. Методология музыкознания и проблемы музыкальной культурологии. К 50 летию педагогической деятельности. Одесса: Астропринт, 2015. 532 с.

6. Лосев А. Античная музыкальная эстетика. М.: Музыка, 1960. 194 с.

7. Маркова Е. Интонационность музыкального искусства. Киев: Музична Україна, 1990. 182 с

8. Муравська О.В. Східнохристиянська парадигма європейської культури і музика XVIII-XX століть: монографрія. Одеса: Астропринт, 2017. 564 с.

9. Уилсон-Диксон Э. История христианской музыки. СПб.: Мирт, 2003. 428 с.

10. Pahlen K. Das neue Opernlexikon. München: Seehamer Verlag, 2000. 1023 S.

\title{
References
}

1. Asafiev, B. (1971). Symphonic etudes. Leningrad, Muzyka [in Russian].

2. Hegel, G. (2017). The Lectures on histories of philosophy. Retrieved from https://mybook.ru/author/fridrihgegel/lekcii-po-istorii-filosofii-2/read/

3. Gudman F. (1995). Magic symbols. Moscow: Zolotoy vjek [in Russian].

4. Druskin, M. (1980). History of foreign music. The Second half XIX age. Moscow, Muzyka [in Russian].

5. Kaminskaja-Markova, E.N. (2015). The methodology musicology and problems music culturology. To 50 years of pedagogical activity work. Odessa, Astroprint [in Ukrainian].

6. Losjev, A. (1960). Antique music esthetics. Moscow: Muzyka [in Russian].

7. Markova E. (1990). Intonation type of music art. Kyiv: Muzychna Ukrajina [in Ukrainian].

8. Muravskaja O. (2017). The east-Christian paradigm of the European culture and music XVIII-XX century: monograph. Odessa: Astroprint [in Ukraine].

9. Wilson-Dickson A. (2003). A brief history of Christian music. S.-Peterburg: Mirt [in Russian].

10. Pahlen K. (2000). Das Neue Opernlexikon. München: Seehamer Verlag [in Germany].

Стаття надійшла до редакції 11.09.2019 p. Прийнято до публікації 10.10.2019 р.

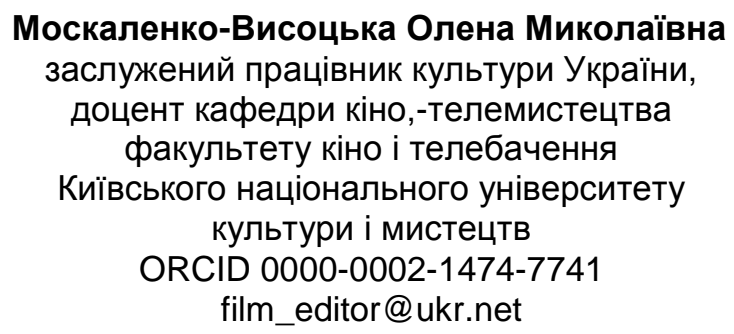

\section{ОСОБЛИВОСТІ РЕЛЕВАНТНОСТІ УКРАЇНСЬКОЇ ЕКРАНІЗАЦІЇ}

\begin{abstract}
Мета дослідження - виявлення характерних рис української екранізації в період 70-х років XX століття шляхом дослідження питань, пов'язаних з встановленням взаємозв'язку між фрільмом та літературним першоджерелом; визначення міри залежності відмінностей фільму від твору письменника, а також ступінь релевантності, відповідності книги і фільму. Методологічною основою дослідження є герменевтичні інтерпретації, що базуються на порівняльному аналізі ігрових фрільмів з літературними першоджерелами, які лягли в основу екранізацій. Предметом дослідження стали фільми "Овод" М. Мащенка, "Лісова пісня. Мавка" Ю. Іллєнка та "Чорна курка та Підземні жителі" В. Греся. Наукова новизна полягає у відкритті принципових моментів концептуальних змін в умовах перекладу літературних творів на мову кіно. На матеріалі українських екранізацій певного історичного періоду, який виявився не достатньо охоплений науковими розвідками, проведені дослідження особливостей трансформації твору з одніє мовної системи в іншу. Висновки. Визначена релевантність українських екранізацій своїм першоджерелам. Простежені змістові трансформації літературних творів, які автономізувалися в самозначущі креативні елементи емблематичних кінотворів вітчизняних режисерів. Запропоновано класифікацію видів екранізації, які умовно можна позначити як "пряма екранізація", "авторська екранізація" та "за мотивами". Встановлено, що на інтерпретацію тлумачення літературної першооснови впливають такі чинники, як особисте авторське розуміння теми та ідеї твору, вплив історичного періоду, в момент якого створюється фільм, соціальні тенденції, що відбуваються в суспільстві та активне звернення до елементів національних традицій як складових для формування естетичних запитів репіцієнтів певної доби.
\end{abstract}

Ключові слова: "пряма" екранізація; "авторська"; екранізація; фільм за мотивами; ігрове кіно.

Москаленко-Высоцкая Елена Николаевна, заслуженный работник культуры Украины, доцент кафедры кино,-телеискусства, фракультет кино и телевидения Киевского национального университета культуры и искусств

Особенности релевантности украинский экранизации

(C) Москаленко-Висоцька О. М., 2020 